\title{
Anopheline Species Complexes in Brazil. Current Knowledge of Those Related to Malaria Transmission
}

\section{Maria Goreti Rosa-Freitas/ ${ }^{+}$, Ricardo Lourenço-de-Oliveira* , Carlos José de Carvalho-Pinto*/**, Carmen Flores-Mendoza*, Teresa Fernandes Silva-do-Nascimento*}

\author{
Laboratório de Sistemática Bioquímica, Departamento de Bioquímica e Biologia Molecular *Laboratório de \\ Transmissão de Hematozoários, Departamento de Entomologia, Instituto Oswaldo Cruz, Av. Brasil 4365, \\ 21045-900 Rio de Janeiro, RJ, Brasil **Departamento de Microbiologia e Parasitologia, \\ Universidade Federal de Santa Catarina, Florianópolis, SC, Brasil
}

A summary of the problems related to the systematics of primary and secondary Brazilian anophelines vectors of malaria is presented.

Key words: Anopheles systematics - species complexes - malaria vectors - Nyssorhynchus - Kerteszia

Many neotropical anopheline species are either candidates or formed by complex of cryptic species. The taxonomic elucidation of these complexes reflects on the epidemiology of malaria transmission and ultimately to the control.

In Brazil, there are 54 species belonging to five subgenera of Anopheles Meigen (Nyssorhynchus, Kerteszia, Stethomyia, Lophopodomyia, Anopheles). Anopheline species reported as human malaria vectors in the country belong to the subgenera Nyssorhynchus and Kerteszia (Deane 1986, Consoli \& Lourenço-de-Oliveira 1994).

In the subgenus Nyssorhynchus, the species found harboring human plasmodia include Anopheles darlingi Root 1926, An. aquasalis Curry 1932, An. albitarsis sensu lato Lynch-Arribálzaga 1878 (including An. deaneorum Rosa-Freitas 1989), An. oswaldoi Peryassú 1922, An. nuneztovari Gabaldon 1940 and An. triannulatus (Neiva \& Pinto 1922). In the subgenus Kerteszia natural infections were reported for An. cruzii Dyar \& Knab 1908, An. bellator Dyar \& Knab 1906 and An. homunculus Komp 1937. It is our opinion that other species reported naturally infected do not play a role in malaria maintenance as they are exophilic, zoophilic, of low density and their distribution and frequency do not coincide with that of malaria. Except for An. darlingi, the natural history of the species listed above points out for zoophilic and/or exophilic behavior in some areas, in such a fash-

${ }^{+}$Corresponding author.

E-mail: mgoreti@gene.dbbm.fiocruz.br

Received 15 June 1998

Accepted 30 July 1998 ion that their role in malaria transmission is doubted (Deane 1986). Are these characteristics an indication that these species are indeed complexes?

To decide whether a given species is high polymorphic or a complex of closely related species, integrated approach studies on distinct populations, including on that of the type-localities and where morphological/behavioral/molecular differences have been reported, are mandatory. Most of the Brazilian anopheline species has been taxonomically investigated by morphology, behavior and molecular tools such as isoenzymes and DNA analyses (mitochondrial and ribosomal DNA restriction analysis, random amplification and sequencing of specific regions) as summarized on Table.

More than $99 \%$ of the malaria cases reported in Brazil occur in the Amazon in which transmission is due to Nyssorhynchus species only.

An. darlingi is the most important Brazilian malaria vector (Shannon 1933, Rachou 1958). The species is the most anthropophilic and endophilic among the Amazonian anophelines. It is frequently found infected and its distribution and density are clearly related to malaria transmission. Even though many populations of the species have been lately reported as biting outdoors, An. darlingi continues successfully transmitting malaria both indoors and at the close vicinity of the houses (Lourenço-de-Oliveira 1995). Isoenzymatic, behavioral and mitochondrial DNA studies on either Brazilian (Rosa-Freitas et al. 1992, Freitas-Sibajev et al. 1995) or other Latin-American (Manguin et al. 1998) populations, showed that An. darlingi is a monotypic species.

An. aquasalis is the lowland coastal vector in Brazil. Chromosomal banding pattern and mtDNA 
TABLE

Summary of differences in behavior, morphology, isoenzyme, mtDNA, rDNA, RAPD and cytogenetic data reported in the literature for populations of neotropical anopheline species related to malaria transmission

\begin{tabular}{|c|c|c|c|c|c|c|c|c|c|}
\hline Species & Behavior & Morphology & Isoenzyme & mtDNA & $\begin{array}{l}\text { rDNA } \\
\text { (ITS2) }\end{array}$ & RAPD & Cytogenetics & References & Conclusion \\
\hline Anopheles darlingi & $\begin{array}{l}1 \\
\text { (Peak and place } \\
\text { of biting) }\end{array}$ & $\begin{array}{l}\text { (Except from } \\
\text { Belize) }\end{array}$ & a & a & ND & ND & 1 & $\begin{array}{l}\text { Consoli \& Lourenço-de-Oliveira } 1994 \\
\text { Freitas-Sibajev et al. } 1995 \\
\text { Harbach et al. } 1993 \\
\text { Kreutzer et al. } 1972 \\
\text { Manguin et al. } 1998 \\
\text { Rosa-Freitas et al. } 1992\end{array}$ & Monotypic \\
\hline An. aquasalis & $\begin{array}{l}1 \\
\text { (Host and place } \\
\text { of biting) }\end{array}$ & $(\mathrm{Egg})$ & a & 1 & a & ND & a & $\begin{array}{l}\text { Conn et al. 1993a } \\
\text { Cova-Garcia et al. } 1977 \\
\text { Flores-Mendonza } 1994 \\
\text { Monaca-Perez \& Conn } 1991\end{array}$ & $\begin{array}{l}\text { High } \\
\text { polymorphic } \\
\text { (UI) }\end{array}$ \\
\hline An. albitarsis & $\begin{array}{l}1 \\
\text { (Host and place } \\
\text { of biting) }\end{array}$ & $\begin{array}{l}\text { (Except } A n \text {. } \\
\text { deaneorum) }\end{array}$ & 1 & 1 & ND & 1 & 1 & $\begin{array}{l}\text { Kreutzer et al. } 1976 \\
\text { Narang et al. } 1993 \\
\text { Rosa-Freitas et al. } 1990 \\
\text { Wilkerson et al. } 1995\end{array}$ & $\begin{array}{l}\text { Complex } \\
\text { (4 species) }\end{array}$ \\
\hline An. oswaldoi & $\begin{array}{l}1 \\
\text { (Host and place } \\
\text { of biting) }\end{array}$ & $\begin{array}{l}1 \\
\text { (Male } \\
\text { genitalia) }\end{array}$ & UI & ND & 1 & ND & ND & $\begin{array}{l}\text { Causey et al. } 1946 \\
\text { Consoli \& Lourenço-de-Oliveira } 1994 \\
\text { Flores-Mendoza pers. comm. } \\
\text { Klein \& Lima } 1990 \\
\text { Marrelli et al. } 1998\end{array}$ & $\begin{array}{l}\text { Complex: } \\
\text { (at least } 2 \\
\text { forms - UI) }\end{array}$ \\
\hline An. nuneztovari & $\begin{array}{l}1 \\
\text { (Host and place } \\
\text { of biting) }\end{array}$ & $\begin{array}{l}\text { (Egg, male } \\
\text { genitalia } \\
\text { and female) }\end{array}$ & 1 & 1 & 1 & ND & 1 & $\begin{array}{l}\text { Delgado \& Rubio-Palis } 1992 \\
\text { Fritz et al. } 1994 \\
\text { Hribar 1994, } 1995 \\
\text { Linley et al. } 1996\end{array}$ & $\begin{array}{l}\text { Possibly a } \\
\text { complex }\end{array}$ \\
\hline An .triannulatus & a & $\begin{array}{l}1 \\
\text { (Male genitalia, } \\
\text { larva and egg) }\end{array}$ & 1 & 1 & ND & 1 & ND & $\begin{array}{l}\text { Silva-do-Nascimento1995 } \\
\text { Silva-do-Nascimento pers. com. }\end{array}$ & $\begin{array}{l}\text { Complex: } \\
\text { (at least } 2 \\
\text { species - UI) }\end{array}$ \\
\hline An. cruzii & (Acrodendrophily) & (Larva) & ND & ND & 1 & ND & 1 & $\begin{array}{l}\text { Deane et al. } 1971 \\
\text { Malafronte et al. } 1997 \\
\text { Ramirez et al. } 1989 \\
\text { Zavortink } 1973\end{array}$ & $\begin{array}{l}\text { High } \\
\text { polymorphic } \\
\text { (UI) }\end{array}$ \\
\hline
\end{tabular}

ND: non determined; UI: under investigation. 
restriction profiles of specimens from Venezuela and Brazil were identical (Moncada-Pérez \& Conn 1991, Conn et al. 1993a). Isoenzymes from three populations of Venezuela and Surinam (Steiner et al. 1981) and two from Brazil (Flores-Mendoza 1994) with behavioral differences also revealed only intraspecific variation. Egg morphology of $A n$. aquasalis varies intraspecifically (Maldonado et al. 1997). In fact, variation was seen in a single female oviposition (Flores-Mendoza 1994). Results of mitochondrial DNA and egg morphology analyses however, suggest that there might be an interspecific division in An. aquasalis populations north and south of the Amazon River delta (Conn et al. 1993a, Linley et al. 1993).

An. albitarsis is a complex formed by, at least, four sibling species: An. marajoara Galvão \& Damasceno 1942, An.albitarsis sensu stricto Lynch-Arribálzaga 1878, An. deaneorum and a fourth form to be formally described (Rosa-Freitas et al. 1990, Wilkerson et al. 1995). Since An. deaneorum is the only morphologically distinguishable member of the albitarsis complex, the role of each member in malaria transmission has not been determined yet. The incrimination of other members of the complex, except An. deaneorum (Klein et al. 1991a, b), were based solely on their presumed geographical distribution.

An. oswaldoi has been regarded as a potential malaria vector in some localities of the Amazon (Arruda et al. 1986, Oliveira-Ferreira et al. 1990, Branquinho et al. 1996) although some authors believe that most populations of this species are much more related to the natural environment and prefer to feed on animals than on man indoors (Deane et al. 1948, Consoli \& Lourenço-deOliveira 1994, Lourenço-de-Oliveira \& Luz 1996). The taxonomic status of the species is under investigation $(\mathrm{PhD}$ work of $\mathrm{CFM})$. Preliminary results from morphological analyses demonstrate that at least two forms are present under An. oswaldoi: An. oswaldoi sensu stricto and An. konderi Galvão \& Damasceno 1942, distinguished pratically only by the shape of the apex of aedeagus (Causey et al. 1946, Lounibos et al. 1997).

Morphology, behavior, cytogenetics, isoenzymes and mtDNA studies favor the existence of at least two cryptic species in An. nuneztovari: one in Venezuela and Colombia northwest of Orinoco and another in the Amazon (Conn et al. 1993b, Fritz et al. 1994, Linley et al. 1996). The species is considered a primary malaria vector in Venezuela and Colombia (Gabaldon 1969, Gabaldon et al. 1975). In Brazil however, the species is not related to malaria transmission, although natural infection by Plasmodium vivax has been detected in areas where darling $i$ was the primary vector (Arruda et al. 1986).

An. triannulatus is constituted by at least three sibling forms. These forms can be differentiate morphologically (egg, larva and male genitalia) and isoenzymatically (Silva-do-Nascimento 1995). The typical triannulatus is the most known and largely distributed form. The other two forms seem to be restricted mostly to central Brazil and are not related to malaria transmission.

The mosquitoes of the subgenus Kerteszia share the common characteristic of using bromeliads as breeding places. An exception is An. (Ker.) bambusicolus Komp 1937 that also breeds in bamboo.

An. (Kersteszia) cruzii and An. bellator were primary vectors of the malaria once endemic in southeastern/southern Brazil (Rachou 1958). An. cruzii is currently involved in the maintenance of the oligosymptomatic malaria occurring in the valleys of the Atlantic Coastal Rain Forest in both Rio de Janeiro and São Paulo states (Carvalho et al. 1988, Azevedo 1997, Branquinho et al. 1997). Larval differences were observed in An. cruzii populations from Rio de Janeiro and Santa Catarina (Zavortink 1973). Besides, chromosomal banding pattern differences were also found among several An. cruzii populations (Ramirez 1989, Dessen pers. comm.). An. homunculus is a morphologically close related species and there is the possibility of being a sibling species in the cruzii complex $(\mathrm{PhD}$ work of CJCP). The remaining Kerteszia species do not seem to be important in malaria transmission in Brazil.

In summary, An. darlingi is a monotypic species. An. aquasalis and An. nuneztovari are possibly complexes. An. albitarsis, An. triannulatus and An. oswaldoi are complexes of species. Anopheline species of the subgenus Kersteszia are still under investigation (Table).

The refinement of the taxonomic tools and the addition of other populations are likely to lead to new insights into the knowledge and understanding of the neotropical species complexes.

\section{REFERENCES}

Arruda ME, Carvalho MB, Nussenzweig RS, Maracic M, Ferreira AW, Cochrane AH 1986. Potential vectors of malaria and their different susceptibility to Plasmodium falciparum and $P$. vivax in northern Brazil identified by immunoassay. Am J Trop Med Hyg 35: $873-881$.

Azevedo AL 1997. Aspectos da Epidemiologia da Malária e da Biologia de Anopheles (Kerteszia) cruzii Dyar \& Knab em Vales Montanhosos do Sistema de Mata Atlântica, MSc Thesis, Instituto Oswaldo Cruz , Fiocruz, Rio de Janeiro, 94 pp.

Branquinho MS, Araujo MS, Natal D, Marrelli MT, Rocha RM, Taveira FA, Kloetzel JK 1996. Anoph- 
eles oswaldoi a potential malaria vector in Acre, Brazil. Trans R Soc Trop Med Hyg 90: 233.

Branquinho MS, Marrelli MT, Curado I, Natal D, Barata JM, Tubaki R, Carreri-Bruno GC, de Menezes RT, Kloetzel JK 1997. Infecção de Anopheles (Kerteszia) cruzii por Plasmodium vivax e Plasmodium vivax variante VK247 nos municípios de São Vicente e Juquitibá, São Paulo. Rev Panam Salud Pública 2: 189-193.

Carvalho ME, Glasser CM, Ciaravolo RMC, Etzel A, Santos LA, Ferreira CS 1988. Sorologia de malaria vivax no foco Aldeia dos Índios, município de Peruíbe, São Paulo, de 1984 a 1986. Cad Saúde Públ 4: 276-292.

Causey OR, Deane LM, Deane MP 1946. Studies on Brazilian anophelines from the northeast and Amazon regions. II. An illustrated key by male genitalia characteristics for the identification of thirty-four species of anophelini, with a note on dissection technique. Am J Hyg Mono Series 18: 21-31.

Conn JE, Cockburn AF, Mitchell SE 1993a. Population differentiation of the malaria vector Anopheles aquasalis using mitochondrial DNA. J Hered 84: 248-253.

Conn JE, Rangel-Puertas Y, Seawright J 1993b. A new cytotype of Anopheles nuneztovari from Western Venezuela and Colombia. J Am Mosq Control Assoc 9: 294-301.

Consoli R, Lourenço-de-Oliveira R 1994. Principais Mosquitos de Importância Sanitária no Brasil, Ed. Fiocruz. 225 pp.

Cova-Garcia P, Pulido J, Amarista RJ 1977. Anopheles (Nyssorhynchus) deltaorinoquensis n. sp. (Diptera: Culicidae) de Venezuela. Bol Dir malariol San Amb 17: $150-160$.

Deane LM 1986. Malaria vectors in Brazil. Mem Inst Owaldo Cruz 81(Suppl.II): 5-14.

Deane LM, Causey OR, Deane MP 1948. Notas sobre a biologia do anofelinos das regiões nordestina e amazônica do Brasil. Rev Serv Esp Saúde Publ 1: 827-965.

Deane LM, Deane MP, Ferreira-Neto JA, Almeida FB 1971. On the transmission of simian malaria in Brazil. Rev Inst Med Trop São Paulo 13: 311-319.

Delgado N, Rubio-Paris Y 1992. Morphometric characterization of the malaria vector Anopheles nuneztovari (Diptera: Culicidae) from Western Venezuela. Mosq Syst 24: 241.

Flores-Mendoza C 1994. Um Estudo sobre Alguns Aspectos Comportamentais, Morfológicos e Bioquímicos de Anopheles aquasalis Curry 1932, MSc Thesis, Instituto Oswaldo Cruz, Rio de Janeiro, $172 \mathrm{pp}$.

Freitas-Sibajev MGR, Conn J, Mitchell S, Cockburn AF, Seawright JA, Momen H 1995. Mitochondrial DNA and morphological analyses of Anopheles darlingi populations from Brazil. Mosq Syst 27: 79-85.

Fritz GN, Conn J, Cockburn A, Seawright J 1994. Sequence analysis of the ribosomal DNA internal transcribed spacer 2 from populations of Anopheles nuneztovari. Mol Biol Evol 11: 406-416.

Gabaldon A 1969. Global malaria erradication: changes of strategy and future outlook. Am J Trop Med Hyg 18: 641-656.

Gabaldon A, Martin GG, Sifontes R 1975. Necesidades en el campo de la investigacion del Programa Nacional de Eradicacion y Control de la Malaria de Venezuela. Bol Dir Malariol San Amb 15: 263-285.

Harbach RE, Roberts DR, Manguin S 1993. Variation in the hindtarsal markings of Anopheles darlingi (Diptera: Culicidae) in Belize. Mosq System 25: 192197.

Hribar LJ 1994. Geographic variation of male genitalia of Anopheles nuneztovari (Diptera: Culicidae). Mosq Syst 26: 132-144.

Hribar LJ 1995. Costal wing spot variation within and among progeny of single female Anopheles nuneztovari (Diptera: Culicidae). Mosq Syst 27: 115.

Klein TA, Lima JBP 1990. Seazonal distribution and biting patterns of Anopheles mosquitoes in Costa Marques, Rondônia, Brazil. J Am Mosq Control Assoc 6: 700-707.

Klein TA, Lima JBP, Tada MS 1991a. Comparative susceptibility of anopheline mosquitoes to Plasmodium falciparum in Rondônia, Brazil. Am J Trop Med Hyg 44: 598-603.

Klein TA, Lima JBP, Tada MS, Miller R 1991b. Comparative susceptibility of anopheline mosquitoes in Rondônia, Brazil, to infection by P. vivax. Am J Trop Med Hyg 45: 463-470.

Kreutzer RD, Kitzmiller JB, Ferreira E 1972. Inversion polymorphism in the salivary gland chromosomes of Anopheles darlingi. Mosq News 32: 555-556.

Kreutzer RD, Kitzmiller JB, Rabbani MG 1976. Cytogenetically distinguishable populations of the mosquito Anopheles albitarsis. Acta Amazonica 6: 473 481.

Linley JR, Lounibos LP, Conn J 1993. A description and morphometric analysis of the eggs of four South American populations of Anopheles aquasalis. Mosq Syst 25: 198-214.

Linley JR, Lounibos LP, Conn J, Duzak D, Nishimura N 1996. A description and morphometric comparison of eggs from eigth geographic populations of the South American malaria vector Anopheles (Nyssorhynchus) nuneztovari. J Am Mosq Control Assoc 12: 275-292.

Lounibos LP, Duzak D, Linley JR 1997. Comparative egg morphology of six species of the Albimanus Section of Anopheles (Nyssorhynchus) (Diptera: Culicidae). J Med Entomol 34:136-155.

Lourenço-de-Oliveira R 1995. Qual a importância da hematofagia extradomiciliar do Anopheles darlingi na Amazônia? Rev Patol Trop 23 (suppl.): 100-101.

Lourenço-de-Oliveira R., Luz SLB 1996. Simian malaria at two sites in the Brazilian Amazon. II. Vertical distribution and frequency of anopheline species inside and outside the forest. Mem Inst Oswaldo Cruz 91: 687-694.

Malafronte RS, Marrelli MT, Carreri-Bruno, GC, Urbinatti, PR, Marinotti O 1997. Polymorphism in the second internal transcribed spacer (ITS2) of Anopheles (Kerteszia) cruzi (Diptera: Culicidae) 
from the State of São Paulo, Brazil. Mem Inst Oswaldo Cruz 92 (Suppl. I): 306.

Maldonado V, Finol HJ, Navarro JC 1997. Anopheles aquasalis eggs from two Venezuelan localities compared by scanning electron microscopy. Mem Inst Oswaldo Cruz 92: 487-491.

Manguin S, Wilkerson RC, Conn JE, Rubio-Palis Y, Danoff-Burg JA, Roberts DR 1998. Population structure of the primary malaria vector in South America, Anopheles darlingi using isozyme, RAPD, ITS2 and morphological markers. Am J Trop Med Hyg, in press.

Marrelli MT, Malafronte RS, Flores-Mendoza C, Lourenço-de-Oliveira R, Kloetzel JK, Marinotti O 1998. Polymorphism in the second internal transcribed spacer (ITS2) of ribosomal DNA among specimens of Anopheles oswaldoi. Insect Mol Biol, in press.

Moncada-Pérez A, Conn J 1991. A polytene chromosome study of four populations of Anopheles aquasalis from Venezuela. Genome 35: 327-331.

Narang SK, Klein TA, Perera OP, Lima JB, Tang AT 1993. Genetic evidence for the existence of cryptic species in the Anopheles albitarsis complex in Brazil: allozymes and mitochondrial DNA restriction fragment length polymorphisms. Biochem Genet 31 : 97-112.

Oliveira-Ferreira J, Lourenço-de-Oliveira R, Teva A, Deane LM, Daniel-Ribeiro CT 1990. Natural malaria infections in anophelines in Rondonia State, Brazilian Amazon. Am J Trop Med Hyg 43: 6-10.

Rachou RG 1958. Anofelinos do Brasil. Comportamento das espécies vetoras de malária. Rev Bras Malariol Doenças Trop 10: 145-181.

Ramirez CL 1989. Estudo Cromossômico em uma
População de Anopheles (Kerteszia) cruzii Dyar \& Knab 1909, MSc Thesis, Instituto de Biociências, Universidade de São Paulo, São Paulo, 96 pp.

Rosa-Freitas MG, Broomfield G, Priestmann A, Milligan P, Momen H, Molyneux DH 1992. Studies on cuticular components, isoenzymes and behaviour of 3 populations of Anopheles darlingi from Brazil. $J$ Amer Mosq Control Assoc 8: 357-366.

Rosa-Freitas MG, Deane L, Momen H 1990. A morphological, behavioural and isoenzymatic study in Anopheles albitarsis from 10 populations. Mem Inst Oswaldo Cruz 85: 275-289.

Shannon RC 1933. Anophelines of the Amazon Valley. Proc Entomol Soc Washington 35: 117-143.

Silva-do-Nascimento T 1995. Estudo Taxonômico e Notas sobre a Biologia de Anopheles triannulatus de 8 Localidades, MSc Thesis, Instituto Oswaldo Cruz, Fiocruz, Rio de Janeiro, 88 pp.

Steiner WWM, Kitzmiller JB, Osterbur, DL 1981. On the genetic identity and evolution of the malaria vectors Anopheles aquasalis and Anopheles emilianus. In R Pal, JB Kitzmiller \& T Kanada (eds), Cytogenetics and Genetics of Vectors. Proceedings of a symposium of the XVI International Congress of Entomology, Amsterdam, Elsevier Biomedical, Amsterdam.

Wilkerson RC, Parsons TJ, Klein TA, Gaffigan TV, Bergo E, Consolim J 1995. Diagnosis by random amplified polymorphic DNA polymerase chain reaction of four cryptic species related to Anopheles albitarsis from Paraguay, Argentina and Brazil. $J$ Med Entomol 32: 697-704.

Zavortink TJ 1973. Mosquito studies XXIX. A review of the subgenus Kerteszia of Anopheles. Contr Amer Entomol Inst 9: 1-54. 
Anopheles Species Complex • Maria Goreti Rosa-Freitas et al. 